<原 著 $>$

ウッドチャック肝細胞癌由来細胞培養株樹立に至る Woodchuck hepatitis virus (WHV) DNA の変化および 組み込まれた WHV DNA の存在様式の検討

\begin{tabular}{|c|c|c|c|c|c|c|c|}
\hline 金子 & 周一* & 大島 & 徹* & 児玉 & 一八** & 青山 & 庄* \\
\hline 吉川 & 寛** & 鵜浦 & 雅志* & 福岡 & 賢一* & 松下 & 文昭* \\
\hline 森岡 & 健 ${ }^{*}$ & 田中 & 延善* & 小林 & 健一* & 服部 & 信* \\
\hline
\end{tabular}

要 旨：ウッドチャック肝細胞癌, 同肝細胞癌由来ヌードマウス移植系, 同移植系由来培養細 胞株における WHV DNA の存在様式を系統的に検討した，5例のウッドチャック肝細胞癌の らち少なくとも 4 例に WHV DNA の組み込みを認めた。 3 年におよら゙継代にす拘らず培養細 胞株における WHV DNA の存在様式は, ヌードマウス移植系と同一であり，ウッドキャック 肝細胞癌と類似していた. Southern hybridization 法, Molecular cloning 法による解析では, 培着細胞株に 3 箇所 WHV DNAが組み込まれており，1つはGene Sの終わりから Gene X まで，1つはGene Cから Gene Sまで，1つはGene pre Sから Gene X までであり， Gene Xから Gene Cにかけては組み込まれていなかった. WHV DNAの組み込みが肝細胞癌の発 症に関与し，培養細胞株に組み込まれた WHV DNA が癌細胞の維持に何らかの役割を果たし ていることが示唆された。

卖引用語： woodchuck hepatitis virus Hepatocellular carcinoma DNA integration Hepadna virus Oncogenesis

\section{緒 言}

ヒトB型肝炎ウイルス (HBV) とヒト肝細胞癌の密 接な関連は疫学的によく知られてきだ。しかしなが ら両者の関連を検討する実験的フブローチには, HBV がヒトやチンバンジーなど限られた宿主にしか感染し ないことや，肝細胞培養株の HBV 感染系が樹立され ていないことなどから，多くの制限が存在している. ウッドチャック肝炎ウイルス (WHV) 2) は HBV と 共に一パドナゥイルス (Hepadna virus) ${ }^{3)} に$ 属し, 感 染実験で高率に肝細胞癌を合併し発癌性の強いウイル スであることが示されている゙!。のためウッド チャック肝細胞癌は HBV 関連七ト肝細胞癌の格好の 実験モデルと考えられ，著者らは，ウッドチャック肝 細胞癌由来邓ードマウス移植系5)，同移植系由来培羕

- 金沢大学第 1 内科

*金沢大学がん研究所生物物理部

<受付日60年11月26日 $>$
細胞株（WH257GE10）定樹立し，報告してきた。

最近, ヒト肝細胞癌染色体 DNA 組み込まれている事実が示され7 ${ }^{711}$, 肝細胞癌の発症 にHBV DNA の組み込みが何らかの直接的役割を果 たしていることが示唆されてきた。

今回 WHVによる発癌機序を解明する目的で, 著者 らが樹立した培養細胞株に至るまでの WHV DNAの 変化と, 組み込まれた WHV DNA の存在様式を検討 し, 若干の考察を加えたので報告する.

実験材料ならびに方法

\section{1. 実験材料}

ウッドチャック肝細胞癌はWHV 表面抗原 (WHsAg) 持続陽性ウッドチャック 5 匹 (No. 1, 5, 11, 13，19）より得られた。これまで報告してきだ,6)よう に, ヌードマウス移植系はNo. 5のウッドチャック䀒 細胞癌の一つをヌードマウスに移植したもので，今回 は継代 8 代目の移植肝細胞癌を用いた。 また， 4 代目 
のヌードマウス移植肝細胞癌より培羕細胞株 (WH257 GE10)は樹立され，今回は継代100代目の細胞を使用し た.

\section{Southern hybridization 法}

すでに報告した蚆ように細胞および組織よりDNA を抽出後，各種制限醅素（Kpn I, Pvu II はWHV ゲ ノムに切断部位を持たず，Eco RI, Hind III, Pst I は 1 筒所切断部位を有する)で完全消化した，約 $10 \mu \mathrm{g}$ の DNA 試料を $1 \%$ 水平 Agarose gel を用いて電気泳動 し, nitrocellulose filter へ移動させた。次に filter は Nick translation法により ${ }^{32} \mathrm{P}$ 標識したブローブ DNA と hybridization 後, オートラジオグラフィーを 行ないWHV DNA の存在様式を検討した。

\section{Molecular cloning 法}

100 代目の WH257GE10細胞より約 $400 \mu \mathrm{g}$ の DNA を抽出後, 各種浱度の制限素 Eco RI にて部分消化 し, 10〜40\%の sucrose 密度勾配によるバンド沈降遠 心法により分画した。この遠心管の底部より試料を分 取し，電気泳動で15 20Kbの DNAサイズを示す分 画を決定し，この分画から sucrose を透析により除去 し、エタノール沈殿を行ないDNAを調整した。一方, ベクターとして charon 4A を用い，DNA を Eco RI にて完全消化後，同様に sucrose 密度勾配遠心によっ てアーム分画を得た. アームDNA の cohesive 末端が 結合していることを確認後, この $12 \mu \mathrm{g}$ と,ささに用意
したWH257GE10の DNA $6 \mu \mathrm{g}$ をT4 DNA リガーゼ (タカラ) の存在下で $50 \mu \mathrm{g} / \mathrm{m} l$ の系として反応を行 なった、反応後 DNAをエタノール沈殿として回収し， $12 \mu l$ の溶液とした。 この $3 \mu l$ をIn vitro ハッッーシン クキット（Amersham 社）を用いてバッケーシング14 を行ない,フォージライブラリーを調整した。 大腸菌 LE392にフフージライブラリーを感染させ NZYCM 寒天ブレートでブラーク形成を行なった。この際の ハッケージンクの効率は $1.5 \times 10^{6} \mathrm{plaque} / \mu \mathrm{g} \mathrm{arm}$ DNA であった. nitrocellulose filter を寒天に密着し, ファージ粒子を移動させ,この filterをアルカリ変性 後，中和した．次いで filter は Nick translation 法に よっで2Pで標識した WHV DNA をブローブとして hybridization を行ない, オートラジオグラフィーによ り WHV DNAを有するプラークを同定した. ブラー ク単離を 3 回繰り返しWHV DNA を有するクローン を単離精製した。これらのクローンを大量調製し DNA を抽出啳，挿入部分の Eco RI 断片または Hind III 断片を pBR328にサブクローンした。この後，各種 制限酵素を用いて制限䣼素地図を作成しクローンの解 析を行なった。

結 果

1. ウッドチャック肝細胞癌における WHV DNA の存在様式

No. 1, 5,11,13,19のウッドチャック肝細胞癌にお

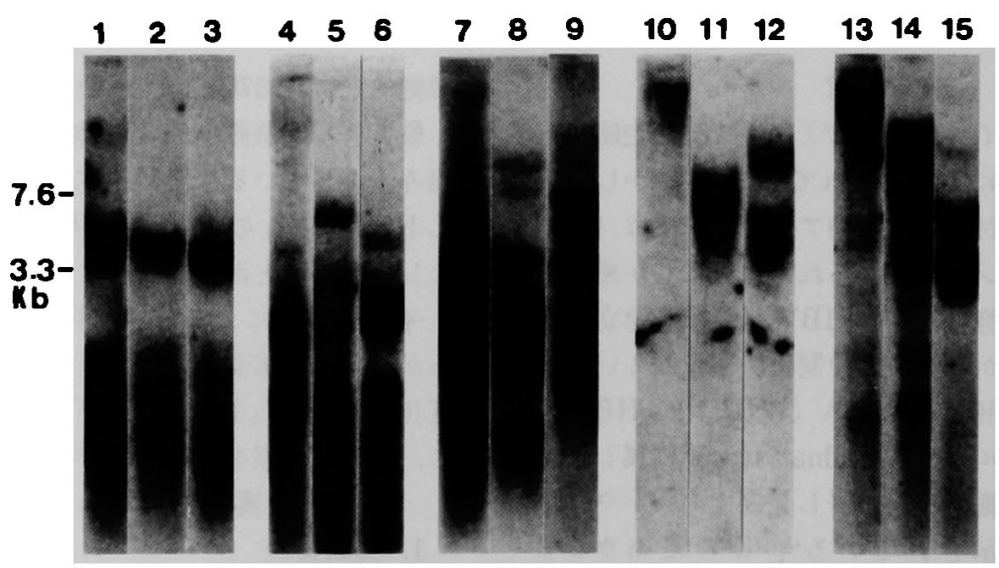

Fig. 1 WHV DNA in 5 woodchuck hepatocellular carcinomas.

DNA samples of No. 13 (lane 1 to 3), No. 1 (lane 4 to 6), No. 5 (lane 7 to 9), No. 11 (lane 10 to 12 ) and No. 19 (lane 13 to 15) were applied onto a $1.0 \%$ horizontal agarose gel without digestion (lane $1,4,7,10$, and 13), after digestion with Pvu II (lane 2, 5, 8, 11, and 14) or with Hind III (lane 3, 6, 9, 12, and 15). Southern hybridization was carried out as described in Materials and Methods. Molecular markers of known length are shown on the left in $\mathrm{Kb}$ (kilobase pairs). 
けるWHV DNA の存在様式をWHVの全ゲノムを ブローブとして Southern hybridization法にて検索 した (Fig. 1). 制限醥末消化のレーン1, 4, 7, 10,13 では, レーン10を除いて Ethidium bromide 蛍光染色 にて確認される染色体 DNAの部位より低分子領域に スメアが認められ,これらは extrachromosomal
WHV DNA と考えられた. また,レーン 1 を除いて染 色体 DNA の位置にバンドが認められ No. 1, 5, 11, 19 の肝細胞癌染色体 DNA への WHV DNA の組み込み が示された。これらの肝細胞澢の制限酵素消化のレー ンでは, WHVゲノムより分子量の大きなバンドが認 められ, Table に示すよらに, それぞれのパンドの数

Table WHV DNA in 5 woodchucks with hepatocellular carcinoma.

\begin{tabular}{|c|c|c|c|c|c|c|}
\hline \multirow{4}{*}{ Woodchuck } & \multicolumn{2}{|c|}{ Nontumorous tissue } & \multicolumn{4}{|c|}{ Hepatocellular carcinoma } \\
\hline & \multirow{3}{*}{$\begin{array}{c}\text { Free and } \\
\text { replicative } \\
\text { intermediates }\end{array}$} & \multirow{3}{*}{ Integration } & \multirow{3}{*}{$\begin{array}{c}\text { Free and } \\
\text { replicative } \\
\text { intermediates }\end{array}$} & \multicolumn{3}{|c|}{ Integration } \\
\hline & & & & \multirow{2}{*}{$\begin{array}{c}\text { No. of } \\
\text { site }\end{array}$} & \multicolumn{2}{|c|}{ Bands in $\mathrm{Kb}(>3.3 \mathrm{~Kb})$} \\
\hline & & & & & Pvu II digested & Hind III digested \\
\hline No. 1 & 世 & - & \# & $>1$ & 6.6 & 5.5 \\
\hline No. 5 & H & - & \# & $>2$ & $8.6,6.6^{*}$ & $6.2,4.3$ \\
\hline No. 11 & NT** & $\mathrm{NT}$ & \pm & $>2$ & $\begin{array}{l}6.2,4.6 \text {, } \\
3.4\end{array}$ & $\begin{array}{l}9.4,9.2 \\
4.3\end{array}$ \\
\hline No. 13 & NT & NT & H & 0 & - & - \\
\hline No. 19 & NT & NT & H & $>2$ & $\begin{array}{l}12.0,9.6 \\
7.6,5.0\end{array}$ & $\begin{array}{l}11.0,5.5 \\
4.5\end{array}$ \\
\hline
\end{tabular}

Sizes of bands larger than $3.3 \mathrm{~Kb}$ (kilobase pairs) are listed from autoradiogram shown on Fig. 1.

- partial digest derived from the $2.2 \mathrm{~Kb}$ band.

* Not tested

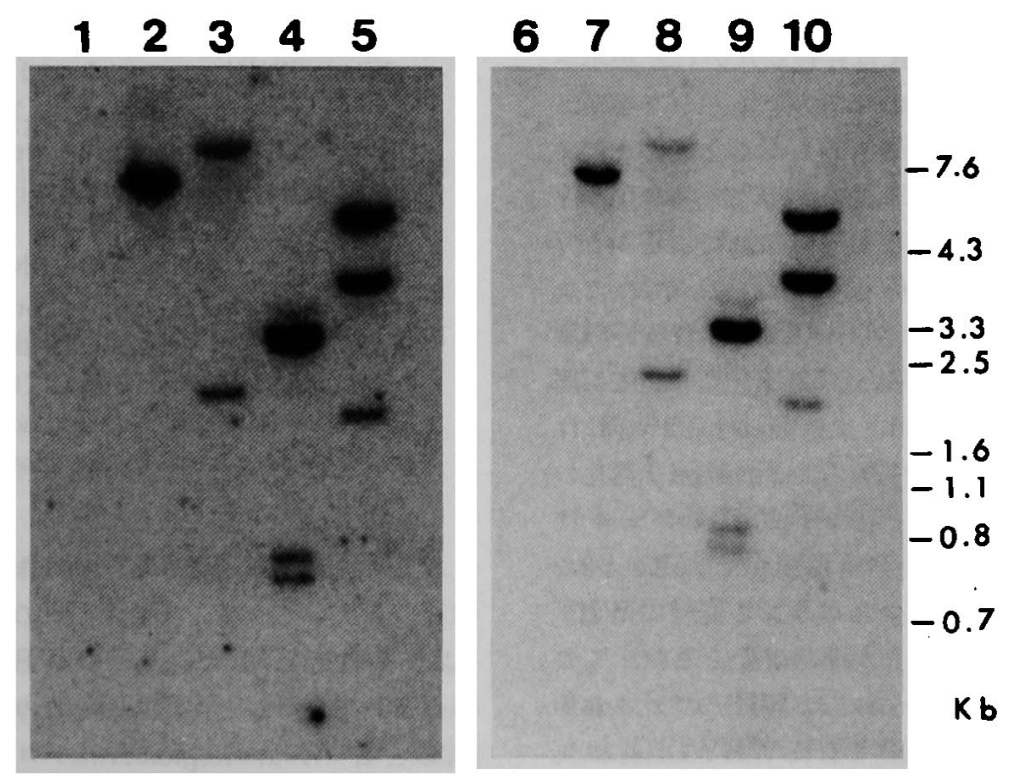

Fig. 2 WHV DNA in the transplanted cell line and WH257GE10.

DNA samples of the transplanted cell line in the 8th passage (lane 1 to 5 ) and WH257GE10 in the 100th passage (lane 6 to 10 ) were applied onto $1.0 \%$ horizontal agarose gels without digestion (lane 1 and 6) or after digestion with Kpn I (lane 2 and 7), with Pvu II (lane 3 and 8), with Eco RI (lane 4 and 9) or with Hind III (lane 5 and 10). Southern hybridization was carried out as in Fig. 1. Molecular markers are shown on the right. 
および位置は各組織により異なっていた。この事実は 肝癌試料に共通して特定の組み込み部位が存在すると の仮説を支持しない. No. 13の肝細胞澏ではレーン1 で染色体 DNA の存在部位と一致して薄いバンドを認 めるが, レーン2，3ではWHVゲノムより大きな分 子量のバンドは明らかでなかった。従って検出感度 (0.1WHV DNA/haploid) 以下の組み込みゃ, 欠失, 再編成を伴った WHV DNA の存在は否定できない が，No. 13に組み込みはないと考光た。いずれにせよ 5 個のウッドチャック肝細胞癌のうち少なくとも 4 個 ではWHV DNA の組み込みが認められ，それらの組 み込みの様式は各々異なっていた。

2. ウッドチャック肝細胞癌由来培卷細胞株 (WH257GE10)樹立に至るまでの WHV DNA の存在 様式

8 代目のヌードマウス移植肝細胞癌と100代目の WH257GE10におけるWHV DNAの存在様式を Southern hybridization 法により比較した (Fig. 2). 制限酔未消化のレーン 1 と6では，染色体 DNA の 存在部位に一致してバンドが認められ (Fig. 2では明 らかではない), 両者にWHV DNAが組み込まれてい ること，他にスメて，ハンドは見られず extrachromosomal WHV DNA は存在しないことが示さ れた。同一制限醳素消化による解析, レーン 2 々 7, レーン 3 と 8, レーン 4 と 9 , レーン 5 と10の比較で は両者に認められるバンドは一致しており, WHV DNA の組み込み部位怙よび組み込まれているWHV DNA の領域には変化がないと考えられた。 なお，これ らの結果は 3 代目， 6 代目のヌードマウス移植肝細胞 癌および38代目，64代目のWH257GE10においてす同 様であった（末発表データ）. 次に Kpn I と Pvu II は WHV ゲノムに切断部位を持たないが，KpnI消化の レーンでは $20 \mathrm{~Kb}$ と $8 \mathrm{~Kb}$ のパンド(20Kbのバンドは Fig. 2では明らかでない), Pvu II 消化では6Kb と2.2 $\mathrm{Kb}$ のハンンドが認められ, 少なくとも2 箇所にWHV DNA の組み込みがあることが示された。 また，この Pvu II における2.2KbのパンドはWHVのゲノムサ イズより小さいため，組み込まれた WHV DNA は欠 失や再編成を伴っていると考兵られた。

組み込まれた WHV DNAをさらに詳細に検討する ため Fig. 3の下段に示すよらなWHV ゲノムの各領 域プローブを作製し, Southern hybridization 法を行 なった (Fig. 3). Fig. 2で示した Eco RI 消化レーンの 約1Kb のハンント 2 本は部分消化の際, 約 $2 \mathrm{~Kb}$ のハンド
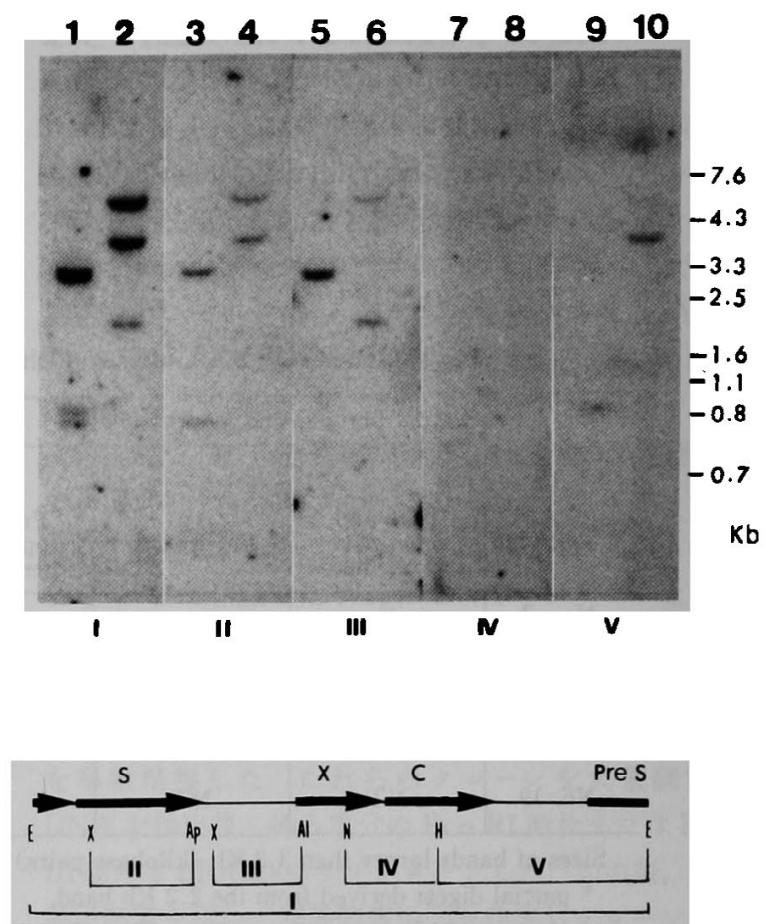

Fig. 3 WHV DNA in WH257GE10 with the probe of whole WHV genome or subcloned fragments of WHV genome.

Whole WHV genome, I, and the locations of the subcloned fragments of the WHV genome, II, III, IV, and V, for the probe were schematically shown in the lower part of the Figure. S, gene $S$; $X$, region $\mathrm{X} ; \mathrm{C}$, gene $\mathrm{C}$; Pre $\mathrm{S}$, region Pre $\mathrm{S}$. Preparation of WH257GE10 DNA and Southern hybridization were carried out as in Fig. 1. WH257GE10 DNA digested with Eco RI (lane 1, $3,5,7$, and 9 ) or with Hind III (lane 2, 4, 6, 8, and 10) were applied onto a $1.0 \%$ horizontal agarose gel. Molecular markers are shown on the right.

となることがわかっているため（未発表データ）両者 は連続していると考えられた。この結果と合わせ Fig. 3より WH257GE10には 3 つの WHV DNA 領域が組 み込まれていることが明らかとなり，仮に Region A, B, C と名つけた. Region A はブローブ III と hybridize し Eco RI の3Kb, Hind III の2Kb のバンドに相当 した. Region Bはプローブ II, V と hybridize し Eco RI の約1Kbのバンド 2 本, Hind III の4Kbのハンンド を形成していた，最後に Region Cはプロープ II, III と hybridize し, Eco RI の3Kb, Hind III の6Kb のハ் ンドを示していた。従って単一に見えるEco RI 3Kb 


\section{$\begin{array}{llllllll}1 & 2 & 3 & 4 & 5 & 6 & 7 & 8\end{array}$}

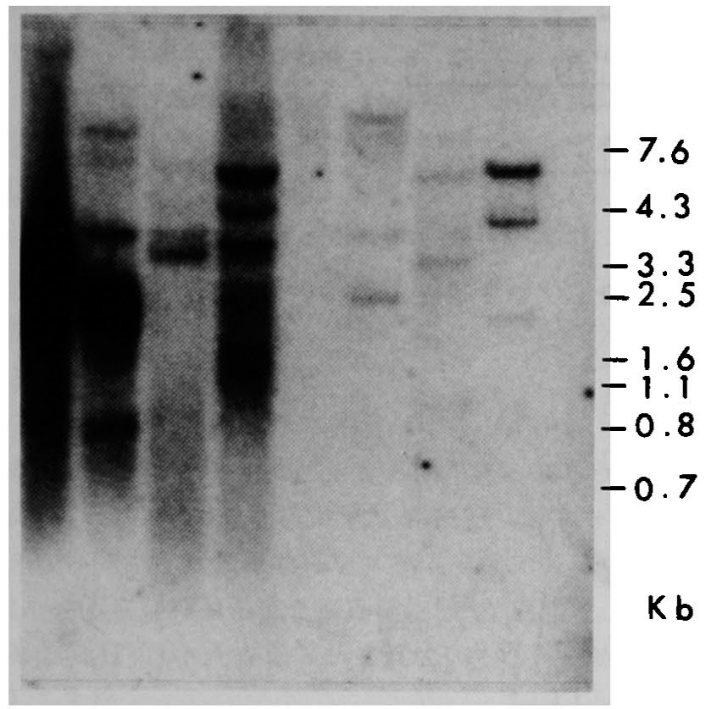

Fig. 4 WHV DNA in No. 5 hepatocellular carcinoma and the transplanted cell line in the 8th passage in an athymic mouse.

DNA samples of No. 5 (lane 1 to 4) and the transplanted cell lines (lane 5 to 8 ) were applied onto a $1.0 \%$ horizontal agarose gel without digestion (lane 1 and 5) or after digestion with Pvu II (lane 2 and 6), with Pst I (lane 3 and 7), or with Hind III (lane 4 and 8 ). Southern hybridization was carried out as in Fig. 1. Molecular markers are shown on the right.

のパンドは異なる 2 種類のパンドより構成されている と考えられる。 またGene Xから Gene Cにかけての ブローブIVのレーン7,8ではバンドが認められず，こ の領域が組み込まれていないことが示され，組み込ま れた WHV DNA はいずれも不完全ゲノムであること が示された。

ヌードマウスへの移植に用いた肝細胞癌は手に入ら ないため, No. 5の多発性結節の他の $1 つ と 8$ 代目の ヌードマウス移植肝細胞癌における WHV DNA の存 在様式を Southern hybridization 法により比較した (Fig. 4). No. 5では extrachromosomal WHV DNA のスメアおよびハンンドが存在するものの, 組み込まれ たWHV DNAのバンドを比較すると Pst I消化の レーン 3 と 7 では $5.5 \mathrm{~Kb}$ のハンドが共通であり, Hind III 消化のレーン 4 と 8 では6Kbのバンドが両者に認 められた。また異なるパンドす存在しており，WH257 GE10の WHV DNA 組み込み様式はNo. 5と同一で
ないと考えられたが，Fig.1に示した他の試料に比し てNo. 5に最も類似していた。

\section{Molecular cloning 法による組み込まれた} WHV DNA の解析

Southern hybridization 法のレベルでは， 3 代目の ヌードマウス移植肝細胞癌から100代目のWH257 GE10に至るまで， 3 年に及ぶ継代にも拘らず外来性の DNA 情報である組み込まれた WHV DNAが安定に 維持されていることが示され，この意味を探るため，

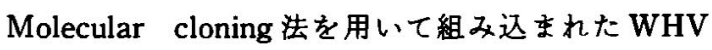
DNAのクローン化を行なった。

In vitroバッケーシンング法にて得られた $2 \times 10^{6}$ 個の プラークから3 個の WHV DNA 陽性のクローン, GE-L2, GE-L6, GE-L8が得られ，これらの制限醭地 四を作製した（Fig. 5).GE-L6と GE-L8は共通の領域 を有するクローンでありこの組み込まれた WHV DNA の領域は Southern hybridization 法の解析から 想定した Region A に一致した. GE-L2は WHV DNA を含むEco RI 断片のサイズから Region B に相当す ると考えられた。

Region A では Hind III と Eco RI の切断点を有す る1.3Kbの領域に WHV DNA が存在し,さらに詳細 にこの部位の制限䣼素地図を作製すると中段の WHV ゲノムに示したよらに, Gene S の終わりから Gene X にかけての WHV DNAが組み込まれていた。 また， この領域の制限酵素部位はよく保たれており，組み込 まれたWHV DNAに大きな欠失や再編成は存在しな かった，GE-L2では挿入 DNA の左端に位置する Eco RI 断片上に WHV DNA が存在し, 詳細な制限酵素地 図を作製すると，中段のWHVゲノムに示したように Gene Cから Gene pre Sの Eco RI 部位にかけて大き な欠失や再編成なしに組み込まれており, Southern 法 の解析で想定した Region Bの一部であることが示さ れた。 また, Fig. 3で示したように,この Region Bの Eco RI 部位には斜線で示した Gene Sの領域が接続 し, 従って左端の Eco RI 部位はウイルスゲノム上の Eco RI 部位と想定された. GE-L2の左端 Eco RI 断片 の塩基配列決定の予備的な結果は上記の結論を支持し ている (未発表データ).

\section{考。察}

$\mathrm{WHV}^{21}$ は, HBV を含むへパドナウイルス ${ }^{31} に$ 属し， HBV と同じく宿主に持続感染し慢性肝炎, 肝細胞癌 の発症を認める ${ }^{2 !}$.とりわけ肝細胞癌の合併は他の一 ミドナゥイルスに比して極めて高率であり, 感染実 
RegionA

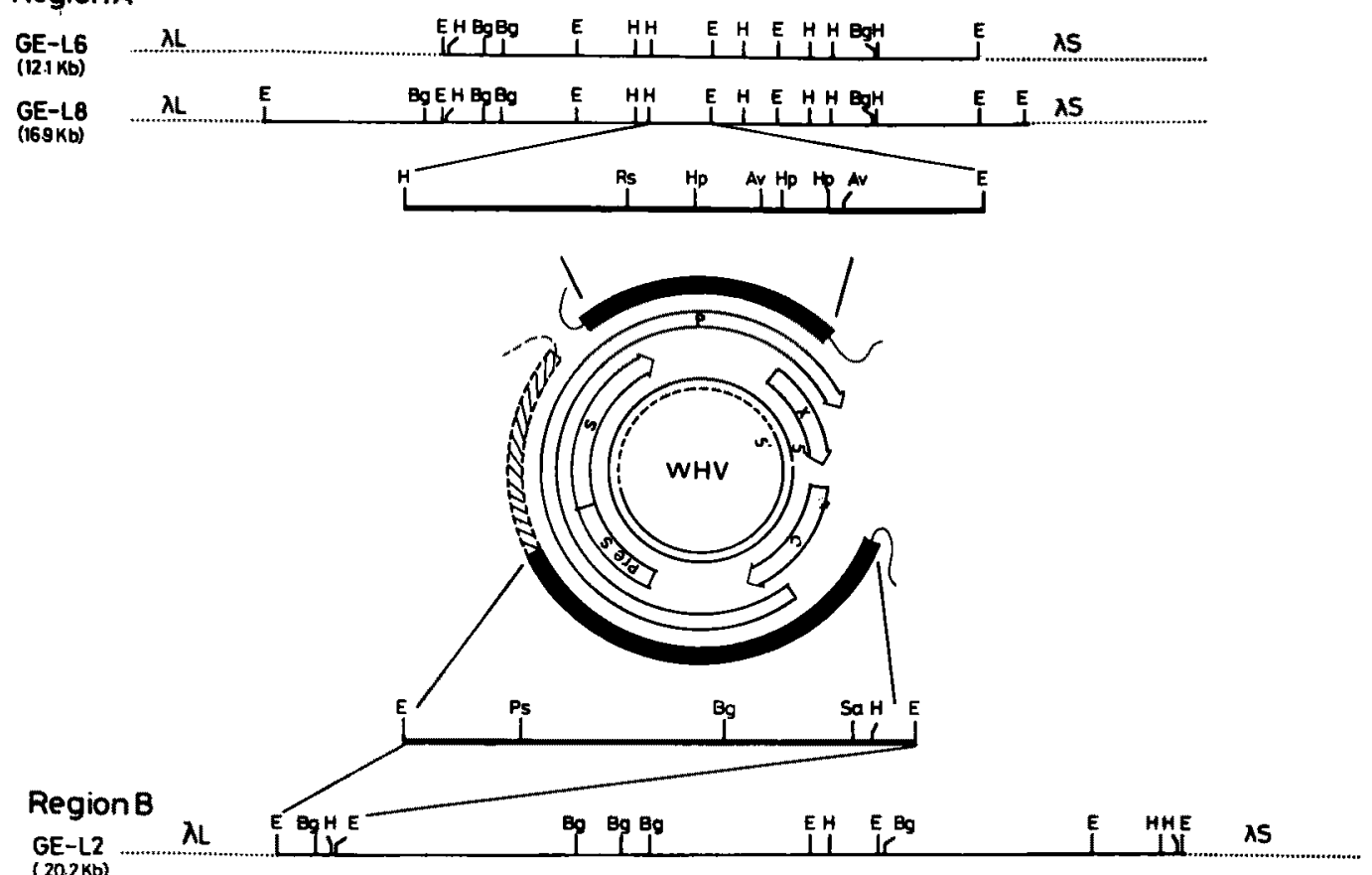

$\mathrm{GE}-\mathrm{L} 2$
$(202 \mathrm{~Kb})$

Fig. 5 Restriction maps of cloned regions of WH257GE10 and the genome structure of WHV.

Restriction maps of three clones isolated from a genomic library of WH257 GE10 were made from results of several combinations of single or double digestions with appropriate restriction enzymes. Two clones GE-L6 and GE-L8 are considered to be derived from the same region, region A, of WH257GE10 since results of restriction mappings and Southern hybridizations indicate that both clones shear the four identical Eco RI fragments in the same order.

Region A (Top) : GE-L6 has about $10 \mathrm{~Kb}$ insertion and GE-L8 has the same insert and additional two Eco RI fragments. Below the restriction maps of the two clones, a fine map of the internal $1.3 \mathrm{~Kb}$ Hind III-Eco RI fragment having WHV DNA is shown in an expanded scale. The relative locations of restriction sites covering more than $0.7 \mathrm{~Kb}$ are the same as those in the WHV genome.

WHV genome (Middle): Structure and genetic organization of the WHV genome (3) are shown inside and restriction sites of the regions of the genome corresponding to region $A$ and $B$ are indicated outside. The shaded part is the region which is not cloned yet but deduced to be next to the cloned Eco RI fragment by the results of Southern blotting (Fig. 4 and the $2.0 \mathrm{~Kb}$ band of EcoRI partial digest shown in lane 4 of Fig. 5).

Region B (Bottom) : GE-L2 has a 1.2 Kb Eco RI fragment flanked to the left arm of charon $4 \mathrm{~A}$. The fragment can hybridize with the WHV probe and its fine map of restriction sites are shown in an expanded scale. The relative locations of restriction sites of the fragment from the left Eco RI site to the Hind III site are the same as those in the WHV genome.

Restriction enzyme cleavage sites are : E, Eco RI ; H. Hind III ; Bg, Bgl II ; Rs, Rsa I; Hp, Hpa II ; Av, Ava II ; Ps, Pst I ; sa, Sac I respectively. 
験”によっても確認されており,ウッドチャック肝細 胞癌は HBV 関連肝細胞癌の発症機序を解明するうえ で格好の実験モデルと考えられている。

HBV DNAがヒト肝細胞澏の染色体 DNAに組み 込まれている事実より ${ }^{7-11}$, 肝細胞癌の発症に HBV DNAの組み込みが何らかの直接的な役割を果たして いる可能性が示唆され，これまで多くの研究がされて きた。しかしゥイルスの感染，増殖様式や組み込みの 様式なども明らかでなく HBVによる発癌機序は依然 として不明のままである.

著者らはこの課題への接近として，安定して再現性 の高い材料を用いて検討する必要があると考え，すで に報告してきたよらにWHV 持続感染ウッドチャッ クから発生した肝細胞癌をヌードマウスに継代移植ら し，さらに同移植系より培養細胞株6を樹立し，両実験 系にWHV DNAが組み込まれていることを明らかに してきた。

ウッドチャック肝細胞癌 5 例のらち少なくとも 4 例 では, WHV DNAの組み込みがあり，これまで報告さ れていたより高率15,16)でありこれは HBs 抗原陽性症 例のヒト肝細胞癌では極めて高率に HBV DNA の組 み込みが認められることと同様であった。他方，慢性 肝炎の試料や非癌部試料で WHV DNA 組み込みは 我々の検出感度以内て確認出来ず，これらの試料での WHV DNA 組み込みは低率であることが示唆され る. 癌部と非癌部における組及込乘の差異はウイル スゲノム組み込みの発癌との深い関連を示すものと考 えられる。

3 代目から8代目のヌードマウス移植肝細胞癌ま で, および 4 代目のヌードマウス移植肝細胞癌から作 られた培養細胞㧣の 100 代目に至るまで 3 年に及ぶ継 代，移植にす拘らず，外来性の遺伝子である組み込む れた WHV DNA は変化することなく保たれていた. この事実は組み込まれた WHV DNA が癌細胞の維持 に何らかの働きをしていることを強く示唆している。 WH257GE10では組み込まれた WHV DNA 3 箇 所存在し，この領域を Region A, B C C とした。現在 までのところ，2つの領域がクローニンクされており Region A は Gene Sの終わりから Gene Xにかけて, Region BはGene Cから Gene Sにかけて組み込まれ でり，大きな欠失や再編成は見られず, Summers ら の報告した再編成を伴ったWHV DNAが組み込まれ ているウッドチャック肝細胞癌の例17とは異なってい た.また Gene Xから Gene Cにかけての領域, Dejean
らの報告した ${ }^{18)}$ direct repeat の部位，は組み込まれて いないと考えられた。

WHV DNA 組み込み様式について WH257GE10と 移植に用いた原発肝細胞癌との直接の比較は出来な かったが，同一個体の他の肝細胞癌試料による比較検 討の結果では組み込みバターンは同一ではなく類似し たものであった．従ってヌードマウス移植系の確立の 過程で，特定の組み込みが選択された可能性が示唆さ れた．現在までウッドチャック肝癌培着細胞株は他に なく，またヒト培養肝癌細胞株の例でも樹立に至る経 過中の HBV DNA の存在様式の変化を検討した例は なく，本報告が初めてであり，樹立過程での組み込み 様式の变化の意義づけは不明である.

今後 Region A, B の塩基配例解析ならびに Region Cのクローニンクを行ない, 組み込まれた WHV DNA の肝細胞癌発症に果たす役割について検索を進 めたいと考えている.

本稿の要旨は1985 meeting on Molecular Biology of Hepatitis B viruses, Cold Spring Harbor, New York $k$ て発表した。

\section{文 献}

1) Beasley R, Hwang LY, Lin CC, et al: Hepatocellular carcinoma and hepatitis $B$ virus. Lancet 2 : 1129-1132, 1981

2) Summers J, Smolec JM, Snyder RL: A virus similar to human hepatitis $B$ virus associated with hepatitis and hepatoma in woodchucks. Proc Natl Acad Sci USA 75: 4533-4537, 1978

3) Summers $J$ : Three recently described animal virus models for human hepatitis B virus. Hepatology 1: 179-183, 1981

4) Gerin J, Tennant B, Popper H, et al: Chronic hepatitis and hepatocellular carcinoma in woodchucks following experimental woodchuck hepatitis virus infection. Abstracts of papers presented at the 1985 meeting on Molecular Biology of Hepatitis B viruses. Cold Spring Harbor Laboratory, USA, 1985, p26

5) Kobayashi K, Fukuoka K, Matsushita F, et al : Transplantation of woodchuck hepatocellular carcinoma in nude mice. Hepatology $3: 663$ $-666,1983$

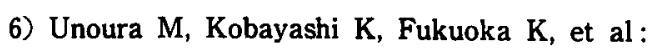
Establishement of a cell line from a woodchuck 
hepatocellular carcinoma. Hepatology 5 : 1106 $-1111,1985$

7) Shafritz DA, Shouval D, Sherman HI, et al: Integration of hepatitis B virus DNA into the genome of liver cell in chronic liver disease and hepatocellular carcinoma. N Eng J Med 305: 1067-1073, 1981

8) Koshy R, Maupas PH, Muller R, et al : Detection of hepatitis virus-specific DNA in the genome of human hepatocellular carcinoma and liver cirrhosis tissues. J gen Virol $57: 95$ $-102,1981$

9) Brechot C, Pourcel C, Hadchouel, et al: State of hepatitis $B$ virus DNA in liver diseases. Hepatology $2: 27 \mathrm{~s}-34 \mathrm{~s}, 1982$

10) Chen DS, Hoyer BH, Nelson J, et al: Detection and properties of hepatitis B virus DNA in liver tissues from patients with hepatocellular carcinoma. Hepatology 2: 42s-46s, 1982

11) Hino O, Kitagawa $T$, Koike $K$, et al: Detection of hepatitis B virus DNA in hepatocellular carcinomas in Japan. Hepatology 4: 90-95, 1984

12）大島 徹, 吉川 寛, 村上清史, 他：ヌードマウス に継代移植されたWoodchuck 肝細胞癌 DNA 中 への Woodchuck 肝焱ウイルスの組み込みについ て. 肝䁍 $25: 998-1003,1984$

13) Maniatis $T$, Fritsch EF, Sambrock J :
Molecular cloning-A laboratory manual. Cold Spring Harbor Laboratory, New York, 1982, p269-308

14) Hohn B, Murray $K$ : Packaging recombinant DNA molecules into bacteriophage particles in vitro. Proc Natl Acad Sci USA 74 : 3259-3263, 1977

15) Summers J, Smolec JM, Werner BG, et al: Hepatitis $B$ virus and woodchuck hepatitis virus are members of a novel class of DNA viruses. In: Viruses in Naturally Occurring Cancers, Cold Spring Harbor Conference on Cell Proliferation, Edited by M Essex, G Todaro, $\mathrm{H}$ zur Hansen. Cold Spring Harbor Laboratory, New York, 1980, p447-457

16) Mitamura $K$, Hoyer $B H$, Ponzetto $A$, et al : Woodchuck hepatitis virus DNA in woodchuck liver tissues. Hepatology $2: 47 \mathrm{~s}-50 \mathrm{~s}, 1982$

17) Ogston CW, Jonak GJ, Rogler CE, et al : Cloning and structural analysis of integrated woodchuck hepatitis virus sequences from hepatocellular carcinoma of woodchucks. Cell 29 : 385-394, 1982

18) Dejean A, Brechot $C$, Tiollais $P$, et al : Characterization of integrated hepatitis $B$ virus DNA cloned from a human hepatoma and the hepatoma derived cell line PLC/PRF/5. Proc Natl Acad Sci USA $80: 2505-2509,1983$ 


\title{
The fate of woodchuck hepatitis virus (WHV) DNA in established tissue culture cells derived from a woodchuck primary hepatocellular carcinoma and the pattern of integrated WHV DNA
}

\author{
Shuichi KaneKo*, Tohru OSHIma*, Kazuya Kodama**, Shou AoYama*, \\ Hiroshi YoshiKawA**, Masashi UNOURA*, Kenichi FUKUOKA*, \\ Fumiaki MATSUSHITA*, Ken MORIOKA*, Nobuyoshi TANAKA*, \\ Kenichi KOBAYASHI*, Nobu HatTORI* and \\ Seishi MURAKAMI**
}

The fate of integrated woodchuck hepatitis viral (WHV) DNA was systematically investigated in DNA samples from primary hepatocellular carcinoma (HCC) of woodchucks, solid tumors transplanted into athymic mice derived from a primary $\mathrm{HCC}$ of woodchuck, and an established cell line of tissue culture originated from the transplanted tumor. In four out of five HCCs, WHV DNA integration was demonstrated. The WHV DNA integrations in the host DNA have been maintained without changing the pattems of bands for more than three years during passages of the transplanted tumors and of tissue culture. Results of Southern hybridization and restriction mappings of cloned fragments suggested that there were three integration sites on the chromosomes of the established cell. A positive role of WHV DNA integration in generation of HCC is strongly suggested by the stable maintenance of a certain mode of WHV DNA integration.

* The First Department of Internal Medicine, School of Medicine, Kanazawa University (Kanazawa)

** Devision of Biophysics, Cancer Research Institute, Kanazawa University (Kanazawa) 